\title{
The Amsterdam Sexual Abuse Case (ASAC)-study in day care centers: longitudinal effects of sexual abuse on infants and very young children and their parents, and the consequences of the persistence of abusive images on the internet
}

Ramón JL Lindauer ${ }^{1,2^{*}}$, Sonja N Brilleslijper-Kater ${ }^{3}$, Julia Diehle ${ }^{1}$, Eva Verlinden ${ }^{1,4}$, Arianne H Teeuw ${ }^{3}$, Christel M Middeldorp ${ }^{5,6}$, Wilco Tuinebreijer ${ }^{4}$, Thekla F Bosschaart ${ }^{3}$, Esther van Duin ${ }^{1,2}$ and Arnoud Verhoeff ${ }^{4,7}$

\begin{abstract}
Background: Little research has been done on the signs of child sexual abuse (CSA) in infants and very young children, or on the consequences that such abuse - including the persistence of the abusive pornographic images on the internet - might have for the children and their parents. The effects of CSA can be severe, and a variety of risk- and protective factors, may influence those effects. CSA may affect the psychosocial-, emotional-, cognitive-, and physical development of children, their relationships with their parent(s), and the relations between parents. In the so called 'the Amsterdam sexual abuse case' (ASAC), infants and very young children were victimized by a day-care employee and most of the victims were boys. Research involving the children and their parents would enable recognition of the signs of CSA in very young children and understanding the consequences the abuse might have on the long term.
\end{abstract}

Methods/design: The proposed research project consists of three components:

(I) An initial assessment to identify physical- or psychological signs of CSA in infants and very young children who are thought to have been sexually abused $(n=130)$;

(II) A cross-sequential longitudinal study of children who have experienced sexual abuse, or for whom there are strong suspicions;

(III) A qualitative study in which interviews are conducted with parents $(n=25)$ and with therapists treating children from the ASAC. Parents will be interviewed on the perceived condition of their child and family situation, their experiences with the service responses to the abuse, the effects of legal proceedings and media attention, and the impact of knowing that pornographic material has been disseminated on the internet. Therapists will be interviewed on their clinical experiences in treating children and parents.

The assessments will extend over a period of several years. The outcome measures will be symptoms of posttraumatic stress disorder (PTSD), dissociative symptoms, age-inappropriate sexual behaviors and knowledge, behavioral problems, attachment disturbances, the quality of parent-child interaction, parental PTSD, parental (Continued on next page)

\footnotetext{
*Correspondence: R.J.Lindauer@amc.uva.nl

'Department of Child and Adolescent Psychiatry, Academic Medical Centre,

Amsterdam, The Netherlands

2De Bascule, Academic Center for Child and Adolescent Psychiatry,

Amsterdam, The Netherlands

Full list of author information is available at the end of the article
} 
(Continued from previous page)
partner relation, and biological outcomes (BMI and DNA).

Discussion: The ASAC-project would facilitate early detection of symptoms and prompt therapeutic intervention when CSA is suspected in very young children.

Keywords: Sexual abuse, Infants, Very young children, Signs, Effects, Internet

\section{Background}

\section{Problem definition}

In late 2010, the Dutch Public Prosecution Service disclosed that a suspected 130 infants and very young children had been sexually abused by a male employee of an Amsterdam day care center. The episode had an enormous impact and drew considerable media attention at home and abroad. This article describes the longitudinal and qualitative study we have now started, which will monitor the abused children over a longer period of time.

International prevalence statistics indicate that 4 to 127 of 1,000 children or adolescents may be involved in child sexual abuse (CSA), depending on the type of informant and the child's gender [1-7]. Prevalence figures are higher for girls than for boys, and $25 \%$ to $35 \%$ of the sexual abuse affects children younger than seven years of age [3].

CSA may produce short-, medium-, and long terms effects in children and parents [8-16]. In the short term, children may develop posttraumatic stress disorder (PTSD), problems with sexuality or sexual behavior, dissociative symptoms, psychosomatic complaints, emotional problems, anxieties, and sleep disturbances [17-31]. In the middle term (two to four years after abuse has ceased), parents report that one half of the children still have fears relating to the threat from the perpetrator(s) [32] and that one half still have serious PTSD symptoms [33]. In the long term, sexually abused children have been found to have a three times higher risk of developing mental health- and physical problems than non-abused children [34-39]. Research has shown that childhood traumatic and stressful experiences can lead to chronic health problems in later life, including cardiovascular disease, obesity, and diabetes $[40,41]$. An Australian study $(\mathrm{N}=2688)$ on the long-term effects of CSA demonstrated that about one quarter of the victims required mental health care over the course of a 43 -year period, as compared to $8 \%$ of the control group [36].

If children who have experienced CSA develop serious health consequences it is partly connected to a range of risk- and protective factors. Risk factors involve the nature of the abuse (penetration makes it worse), the duration and frequency, the amount of violence used, and whether the perpetrator was a family member or relative [42-44]. Protective factors include parental support (if the abuse was outside the family).
A child's temperament also influences whether or not symptoms develop. Although PTSD is always preceded by an environmental factor - the traumatic event - twin studies indicate that genetic factors have a $30 \%-40 \%$ influence on individual differences in susceptibility $[45,46]$. This is comparable to the heritability of other disorders such as depression, yet for PTSD far less research has investigated the influence of genes on the onset of the disorder [47].

Excessive, repeated, or chronic stress in the initial years of life can deregulate the biological stress systems and induce epigenetic modifications - structural changes in DNA that make the DNA at that locus easier or more difficult to read. This affects the degree of expression of a gene, meaning that the risk of developing PTSD symptoms may be influenced not just by congenital genetic variation, but also by epigenetic modifications induced by the trauma [48].

Parents face the awesome task of dealing with their own reactions and feelings without distressing their child any further [49]. Common parental reactions are feelings of guilt, rage against the perpetrator, and fear that the abuse will be repeated in a different setting [50]. Parents have reported that being informed about the sexual abuse of their child, the police questioning, and the media attention are all highly stressful [33]. Parents may develop PTSD and depressive symptoms themselves [50-56]. This can adversely affect their relationships with their child, their partner, and the child's siblings [57-59]. For young children, the quality of the attachment relationship with parents is important for their further development. Traumatic experiences, including sexual abuse, may alter the quality of the attachment relationship to parents; it may become insecure or even disorganized. Alternatively, parental care may have protective effects, with possible positive influences on biological processes such as epigenetic modifications or alterations in the functioning of the HPA axis [45,46,60-66]. Reduced coping capacities and parental concerns about issues such as sexual development (including homosexuality in abused boys) have been found to often raise new problems for families. In about $20 \%$ of cases, a negative spiral emerges that leads to prolonged psychopathology in the child and possibly in the parents.

If child pornography has been made the children are not only victims of the CSA they have suffered, 
but also of the fact that recorded images of the abuse persist [67-69]. The existence of such material can have traumatic effects on the child and the family as well giving the gross violation of their privacy [69]. If the abusive images have been placed on the internet, the children and their parents must live with the permanence of the images, since it is virtually impossible to ever completely remove them. The realization of that permanence, which often does not dawn until later, may trigger feelings of loss of control, helplessness, shame, and fear [69]. At present, little is known about what consequences the dissemination of pornographic material might have for the victimized children, or their parents. Only a few treatment programs exist that focus on these aspects of the victims' experience [67].

In view of the probable serious consequences of CSA in the short-, medium-, and long terms, it is important to ensure early recognition of symptoms and prompt provision of support. Research literature about physical symptoms that might confirm suspicions of sexual abuse in pre-school children is very limited [70-73]. No valid diagnostic instruments are currently available. Barely any research has been conducted on the impact of CSA in the group of infants and very young children, usually this group is subsumed under a broader category labeled 'younger than 6' or 'younger than 12'. Many children who are at risk of CSA are still in the preverbal phase which means that their expressive capabilities are limited [74-77]. Few specific details are known about the clinical picture for very young traumatized children. The limited research on physical injury in young children for whom a strong suspicion of CSA exists has found that just $4 \%$ to $14 \%$ of the children show signs of physical injury [70,78-80].

Although CSA is common, it does rarely occur on the scale that it did in the Amsterdam sexual abuse case, committed by one chief perpetrator with one or two possible accomplices, and the severity of CSA is well documented by the police. CSA has grave consequences for the children involved, their parents, and their families. The quality of the parent-child relationship may be a protective factor. Systematic research on the effects that CSA has on very young children, and on boys in particular, is urgently needed to better understand the psychological and physical clinical presentations of such abuse and to identify the risk- and protective factors for psychopathology resulting from it. This knowledge will enable early recognition of problems and early intervention.

\section{Research questions and objectives}

The purpose of the study is to systematically document the signs and symptoms of sexual abuse in infants and very young children and the short-, medium-, and longterm effects of the abuse, including the effects of the persistence of pornographic internet images, on the children and their parents. The study will examine the psychological, social, emotional, cognitive, and physical development, and developmental problems, of children, the psychological well-being of their parents, and the quality of interactions between parents and children, and between parents. The outcome measures will be symptoms of PTSD, dissociative symptoms, age-inappropriate sexual behavior and knowledge, behavioral problems, attachment disturbances in children, PTSD in parents, the quality of parent-child interaction, parental partner relation, and biological outcomes.

We will investigate the following types of questions:

- Child-focused questions:

$\checkmark$ What signs of sexual abuse of infants and very young children are apparent in the short term?

- What physical injuries do very young sexually abused children have?

- Does a relationship exist between the severity of the abuse (judged from information in police reports and criminal indictments) and the development of trauma symptoms in children?

- Does a relationship exist between parents' own past experiences of abuse and the development of trauma symptoms in their children?

$\checkmark$ How does sexuality and sexual knowledge develop in children for whom early sexual abuse has been confirmed or strongly suspected?

$\checkmark$ What effects of early-age sexual abuse are apparent in the medium- and long terms, and to what extent are these influenced by biological factors?

$\checkmark$ What consequences does the persistence of pornographic internet images have for a child in medium and long terms?

- Parent-focused questions:

$\checkmark$ What psychological consequences are experienced by parents whose child has been abused?

$\checkmark$ What consequences does the persistence of pornographic Internet images have for parents in the medium and long terms?

$\checkmark$ What influence does the sexual abuse have on parental partner relationships?

- Influences of parent-child interaction and family environment:

$\checkmark$ What risk- and protective factors influence the development of symptoms in children and their parents for example social support, attachment problems, parental trauma history? 
$\checkmark$ What influence does the quality of the parentchild relationship have on the development of symptoms in the children?

- Additional questions:

$\checkmark$ What are the experiences of parents who have, and who have not, informed their child about the sexual abuse the child experienced as an infant? If they have informed the child, how and at what age did they do so? What underlying motives do parents have for informing or not informing their children?

$\checkmark$ What clinical experiences are reported by therapists that treat children and parents for the effects of sexual abuse?

\section{Methods/Design}

\section{Project organization}

The following people and groups will be involved in the study: the project leaders, the project group, and a research advisory committee comprised of Dutch and international experts.

The project group will support the three project leaders (RJLL, SNB and AV) in all facets of the study. The project leaders will have charge of the day-to-day practical conduct of the study. The project leaders and the members of the project group will meet regularly. The research advisory committee will be informed once a year in writing and will make recommendations to the project group. Should the subject matter of the study require more consultation, meetings will be scheduled more frequently.

\section{Study design}

\section{Signs of sexual abuse in very young children}

The initial assessment (T0) took place shortly after disclosure of the abuse case in December, 2010. At the Academic Medical Centre (AMC), five outpatient teams were appointed, composed of three types of professionals (pediatrician, parent adviser, and child psychologist or child development expert). Each team made systematic diagnoses of the physical and psychological effects of sexual abuse (confirmed or suspected) in children and their parents. A total of 130 children and their parents were examined; in 126 cases, parents authorized the use of anonymized data for research purposes. For 87 of the children, a criminal case file now exists in which sexual abuse has been demonstrated by investigators and/or acknowledged by the chief perpetrator.

\section{Longitudinal (cross-sequential) study}

We will conduct a cross-sequential longitudinal study $[81,82]$ involving children who have experienced sexual abuse or for whom there are strong suspicions of abuse.
A cross-sequential longitudinal design will enable us to systematically determine the effects of sexual abuse by combining three research techniques: (1) examining the same children at different ages (longitudinal study); (2) examining children of different ages at the same point in time (cross-sectional study); and (3) examining children of different ages at different points in time (cross-sequential study). The longitudinal study started in 2013 (T1). Some children who have experienced sexual abuse or for whom there are strong suspicions of abuse were not involved in the measurements of T0. However, their parents had contact with the Public Health Service during the second aftercare phase as part of the psychosocial support program for accidents and disasters. The Public Health Service provided this aftercare program with the goal to detect psychosocial complaints in traumatized victims. The research project will monitor children and their parents for several years (granted till 2017) to gather firm evidence on long-term effects.

\section{Qualitative study}

In the qualitative study, parents and therapists will be interviewed by a psychologist/researcher. The focus of the parental interviews will be on the perceived condition of their child, their family situation, their experiences with the health and social services, the impact of legal procedures and media attention, the impact of the Internet dissemination of the child pornographic material, and the extent to which they recognize outcomes of the quantitative study. The focus of the interviews of the therapists will be on their experiences of treating children and parents involved in the abuse case.

\section{Study groups}

\section{Signs of sexual abuse in very young children}

This group involves the children who have experienced sexual abuse or for whom there are strong suspicions of abuse $(\mathrm{n}=126)$.

\section{Longitudinal study (cross-sectional)}

The study group as known at the AMC $(\mathrm{n}=126)$, comprised very young children from 4.5 months to 11.2 years of age (median age 3.9 years; 77 boys and 48 girls) who are confirmed or strongly suspected to have experienced sexual abuse (oral, vaginal, and/or anal). Confirmed sexual abuse is defined as abuse that has been demonstrated by police and/or affirmed by the chief perpetrator. Some children who are confirmed or strongly suspected to have experienced sexual abuse were not involved in the AMC study group $(\mathrm{n}=126)$ but had contact with the Public Health Service during the aftercare program. Therefore we proceed on the assumption that parents of 
150 children can be contacted for participation in this research project.

\section{Qualitative study}

This group will involve a subgroup of participating parents. Following the first quantitative assessment in the longitudinal study (T1), parents will be recruited for qualitative interviews $(n=25$; this number will suffice for the qualitative data, as we expect no new information from a larger sample). To recruit the interviewees, we will first compile a comprehensive list of parents who have expressed willingness to take part. From this list, we will select parents for the interviews. In this selection, it will be important to allow for gender, education, SES, ethnicity, and the age at which their child was abused. Therapists from various child and adolescent mental health care agencies will also be selected for interviews.

\section{Informed consent}

The Medical Ethical Committee of the Academic Medical Centre, Amsterdam, the Netherlands approved on the research protocol.

At T0, we requested parents' permission to use the collected data in anonymized form for publication in scholarly journals. After consultation with the medical director, we requested this consent orally and recorded it in the medical file. At the start of the longitudinal study (T1), parents will be requested to also provide written consent for T0.

Parents who took part in the T0 measure will be contacted by or in behalf of AMC-employees who were involved in the T0 measure. Parents will be asked if the Public Health Service may inform them about this longitudinal research project. Parents who are known to the Public Health Service from the second aftercare phase in 2011 will again be contacted by or in behalf of Public Health Service employees who were involved in the after care phase. Parents will be asked if they want to receive information about the longitudinal research project. Parents who want to receive information will be sent written information about the research study. If necessary, researchers will provide more detailed explanations in response to any parental questions. After a couple of days, written consent to participate will be requested. Separate written consent will be obtained from parents who are willing to take part in the study component in which children are also actively involved. Children who are older than 7 and who actively take part in the study will also be provided with information about the research. Children who are older than 11 will also be asked to sign an informed consent form. Children who are not informed about the sexual abuse will not be contacted for this research project. A separate written consent form will be requested from participants who also agree to biological testing.

The reason we have decided on the tiered informed consent procedure is to enable parents to take part in the project who do not wish to inform their child about the abuse. In those cases, we will contact the parents only, and will administer questionnaires and interviews to them about their child.

For examination of police files separate informed consent will be asked. Informed consent will also be asked for information about the received treatment and the effects.

\section{Assessments}

In the present project we describe how we will monitor the children and their parents over a period of many years. This will depend on the ongoing consent of parents (and of children, if aged 12 or older). A number of assessments will take place: T0 (late 2010), T1 (2013), T2 (2014), T3 (2015), T4 (2016), T5 (2017), and T6 (2018).

\section{Assessment instruments}

Background variables: demographic information, severity and type of sexual abuse, other stressors, family problems, legal procedures, and psychological treatment and its effects.

\section{Signs of sexual abuse in very young children} The following assessment instruments were administered at T0 (late 2010):

- Adams classification for genital abnormalities after sexual abuse [83-86]. Photographs of the external genitals were made in the "frog-leg" position (supine with knees bent and foot soles together) and the "polar bear" position (on knees and elbows). The pictures were taken in conformity with the guidelines for identifying physical signs of suspected sexual abuse and were assessed by a team of experts using the Adams classification. The interrater reliability of these assessments will be evaluated.

- Symptom score checklist compiled on the basis of a number of existing questionnaires for assessing mental health and well-being in children and parents, sexual abuse in parents' past history, and family problems;

- The Sexual Knowledge Picture Instrument (SKPI; [87]) for estimating children's sexual development and knowledge;

- Information from police reports and indictments considering (nature and severity of the abuse); Public Health Services questionnaires (general 
questionnaire on demographic data; parental mental health problems such as depression; uptake of available treatment).

\section{Longitudinal study \\ Assessment instruments in the longitudinal study (T1 and further)}

Based on the type of consent that parents have given, we will create three different categories in the sample (assessment including parents only; assessment of parents and children; and assessment of parents and children, including biological testing). This will determine which questionnaires, interviews, observations, and biological tests will be used (see also Tables). All questionnaires will be delivered to parents via a digital link and the children full out the questionnaires at location. Interviews with parents and/or children will be conducted at the child and adolescent psychiatry of the AMC or, at an location of the Public Health Services Amsterdam. If parents prefer, interviews will be conducted at home. The primary outcome measures will be symptoms of PTSD, dissociative symptoms, behavioral problems, age-inappropriate sexual behavior and knowledge, attachment disturbances, the quality of parent-child interaction, PTSD in parents, and parental partner relation.

\section{Assessment instruments: questionnaires and interviews for parents}

Psychological health and well-being of the child (questionnaires and interviews administered to parents only):

\section{- PTSD/trauma symptoms:}

$\checkmark$ CRIES-13, parent version (Children's Revised Impact of Event Scale; [88-90]): a 13-item questionnaire to screen for PTSD symptoms in children. Internal consistency ranges from alpha 0.71 and 0.87. Convergent, divergent, and criterion validity are good [91].

$\checkmark$ DIPA (Diagnostic Infant and Preschool Assessment; [92,93]). The DIPA is a semistructured interview for PTSD and other anxiety disorders as well as mood, behavioral, reactive attachment, and sleep disorders in children up to age 7. The DIPA has been validated, is reliable, and has a test-retest reliability of kappa 0.53 [92].

\section{$\checkmark$ ADIS-C (Anxiety Disorders Interview} Structured for DSMIV-child version, [94]; Dutch version: [95]). This interview investigates PTSD and other anxiety disorders in children aged 8 to 17 years. The ADIS-C demonstrates good to excellent test-retest and inter-rater reliability [96,97].

- Dissociative symptoms: $\checkmark$ CDC (Child Dissociative Checklist; [98]; Dutch translation by [99]). The CDC is a list of 20 questions that provide indications of the presence of dissociative symptoms in children up to age 12 . Test-retest reliability ranges from 0.57 to 0.92 , and internal consistency from alpha 0.64 and 0.95 [98].

- Attachment disturbance symptoms:

$\checkmark$ AISI (Attachment Insecurity Screening Inventory, [100]) Attachment disturbances can be investigated with the AISI. This 20 items questionnaire will be administered to parents with children age 2 to 12 years.

$\checkmark$ GIH (Global Indicatielijst Hechting, [101]). The $\mathrm{GIH}$ is a 36 items questionnaire that investigates attachment disturbances in children older than 12 .

- Sexual behavior (and problems):

$\checkmark$ CSBI (Child Sexual Behavior Inventory; [102]; Dutch translation by [103]). The CSBI is a questionnaire to screen for symptoms of inappropriate sexual behavior under the age of 12 . Reliability is alpha 0.93 , and validity and test-retest reliability are adequate [104].

- General psychological functioning and behavioral problems:

$\checkmark$ CBCL (Child Behavior Checklist; [105]). The $\mathrm{CBCL}$ assesses internalizing and externalizing problems in children aged 1,5 to 17 years. Reliability ranges from alpha 0.71 to 0.89 , validity is adequate, and test-retest reliability is 0.90 [105].

- Quality of life:

$\checkmark$ Kidsscreen-10, parent version [106]. Kidscreen10 is a 10 -item questionnaire on quality of life in children aged 8 to 17 years. Internal consistency is alpha 0.78. [106].

Psychological health and well-being of the parent(s):

- PTSD/trauma symptoms/parental stress:

$\checkmark$ IES-R (Impact of Event Scale-Revised; [107]). The 22-item IES-R questionnaire is completed by parents to screen for PTSD in parents. Internal consistency ranges from alpha 0.79 to 0.90 and validity from 0.53 to 0.72 [107].

$\checkmark$ PERQ (Parent Emotional Reaction Questionnaire; [108]). The 15-item PERQ is completed by parents and assesses their emotional reactions to the sexual abuse of their child. Internal consistency is alpha 0.87 and test-retest reliability 0.90 [108].

- Parental relationship:

$\checkmark$ ECR (Experiences in Close Relationships; [109]; Dutch translation and validation by [110]). The ECR consists of 36 questions scored on a 7point scale, testing two dimensions of attachment in 
adult partner relationships: (1) fear of rejection and abandonment by a partner; and (2) avoidance of intimacy. Internal consistency ranges from alpha 0.78 to 0.93 , and test-retest reliability from 0.82 to 0.89 [111].

\section{Assessment instruments: questionnaires and interview for the child (if consent is given)}

Psychological health and well-being of the child (the following questionnaires and interviews will be administered to the child, the children will have been informed about the sexual abuse):

- PTSD/trauma symptoms:

$\checkmark$ CRIES-13, child version (Children's Revised Impact of Event Scale; [88-90]): a 13-item questionnaire to screen for PTSD in children aged 8 to 17 years. Internal consistency ranges from alpha .74 to .89 . The test-retest reliability coefficient is .85 for the total score. Criterion validity is good [112].

$\checkmark$ CAPS-CA (Clinician-Administered PTSD Scale, child and adolescent version; [113]) is a semistructured clinical interview for children aged 8 to 17 years that enables DSM-IV-TR PTSD diagnoses and severity scores of posttraumatic stress symptoms to be determined on a standardized basis. Internal consistency is alpha 0.83 ; validity and interrater reliability are good [114].

- CPTCI (Child Post-Traumatic Cognitions Inventory; [115]). matically screens for negative thoughts that traumatized children and adolescents, aged 8 to 18 years, might have about themselves or the world around them. Internal consistency, test-retest reliability, and convergent and discriminant validity are good [115].

- Dissociative symptoms:

$\checkmark$ ADES (Adolescent Dissociative Experience Scale; [116]). The ADES is a self-completion questionnaire that assesses dissociative symptoms in children age 12 years and older. Reliability and validity are good [116].

- General functioning and behavioral problems: $\checkmark$ YSR (Youth Self-Report; [105]). The YSR assesses the behavioral and emotional functioning of adolescents (11 years and older), including internalizing and externalizing problems. Internal consistency ranges from 0.55 to 0.75 , validity is good, and test-retest reliability is 0.88 [105].

- Quality of life:

$\checkmark$ Kidscreen-10, child version [106]. Kidscreen-10 is a 10-item questionnaire on quality of life in children aged 8 to 17 years. Internal consistency is alpha 0.82 and test-retest reliability 0.55 [106].
Assessment instruments: observations child/parent (if consent is given)

Quality of parent-child interaction (observations):

- Strange situation procedure $[117,118]$ : During this separation and reunion procedure, the quality of the attachment relationship between children and their parent is assessed.

- A 25-minute video recording will be made of three play situations involving the child and a parent, with degree of control varying by situation: (1) free play, with parent following the child's lead; (2) structured play, with parent taking more of a lead; and (3) tidying up the toys. The video recordings will then be coded using two coding systems: DPICS (Dyadic Parent-child Interaction Coding System; [119]), and EAS (Emotional Availability Scales; [120]).

\section{Assessment instruments: biological measures (if consent is given)}

- Weight and height will be measured and body mass index (BMI) calculated.

- The children's growth charts were requested from the Child Health Center.

- Genetic material (DNA) will be isolated from saliva, after which single nucleotide polymorphisms (SNPs) and methylation status will be determined on a genome-wide basis. This study will examine whether SNPs can be identified that are associated with posttraumatic stress symptoms. We will also analyze whether methylation status affects the degree of symptomatology in the group of abused children $[45,46]$.

\section{Qualitative study}

Individual interviews will be conducted with 25 parents, guided by the following topics: perceived condition of the child and the family situation, experiences with health and social services in the preceding period, experiences with legal procedures, experiences with media attention, viewpoints on the impact of child pornography, in particular on the internet. The interviews will have an open structure. Interviewees will be invited to tell their own story. The subjects in the topic guide will be raised by the interviewer if they fail to come up naturally. The interviewer will probe for respondents' experiences and also experiences of the therapists who treated these children.

\section{Outcome measures}

See Tables 1, 2, and 3 for the outcome measures. 
Table 1 Consent for contact with parents only (questionnaires are adult/parent versions)

\begin{tabular}{|c|c|c|c|c|}
\hline $\begin{array}{l}\text { Assessment } \\
\text { instrument }\end{array}$ & $\begin{array}{l}\text { Questionnaire } \\
\text { or interview }\end{array}$ & Construct & $\begin{array}{l}\text { Standardized/ } \\
\text { validated }\end{array}$ & $\begin{array}{l}\text { Age of the } \\
\text { child }\end{array}$ \\
\hline CRIES & Questionnaire & PTSD symptoms & $\begin{array}{l}\text { yes, in USA and in the } \\
\text { Netherlands }\end{array}$ & $2-18$ years \\
\hline $\begin{array}{l}\text { DIPA or ADIS- } \\
C\end{array}$ & Interview & $\begin{array}{l}\text { diagnosis and symptoms of PTSD, other anxiety disorders, and mood, } \\
\text { behavioral, reactive attachment, and sleep disorders }\end{array}$ & $\begin{array}{l}\text { yes, in USA and a Dutch } \\
\text { study in progress }\end{array}$ & 2-18 years \\
\hline CDC & Questionnaire & symptoms of dissociation & yes, in USA & $5-14$ years \\
\hline AISI or GIH & Questionnaire & symptoms of inhibited and disinhibited attachment & yes, in the Netherlands & 2-18 years \\
\hline CSBI & Questionnaire & symptoms of inappropriate sexual behavior & $\begin{array}{l}\text { yes, in USA Dutch study } \\
\text { in progress }\end{array}$ & $2-12$ years \\
\hline $\mathrm{CBCL}$ & Questionnaire & internalizing and externalizing symptoms & yes, internationally & $\begin{array}{l}1.5-5 \text { years and } \\
6-18 \text { years }\end{array}$ \\
\hline Kidscreen-10 & Questionnaire & quality of life & yes, internationally & 8-18 years \\
\hline IES-R & Questionnaire & parental PTSD symptoms & yes, internationally & parents \\
\hline PERQ & Questionnaire & parental emotional reactions to sexual abuse of child & no & parents \\
\hline ECR & Questionnaire & attachment in adult partner relationships & $\begin{array}{l}\text { yes, in USA and in the } \\
\text { Netherlands }\end{array}$ & parents \\
\hline
\end{tabular}

\section{Time line and sample selection}

Parents were contacted by the AMC or the Public Health Service Amsterdam and invited to take part in the study. Researchers will be employed who will receive training in conducting interviews and observations, and in scoring the observations, from the Child and Adolescent Psychiatry Research Group at the AMC.

The T1 assessments took place in mid-2013, and the data obtained will be processed, analyzed, and reported later. In the first half of 2014, preparations will be made for the T2 assessments. This working procedure will enable us to perform, process, analyze, and report on the

Table 2 Questionnaires/interviews child

\begin{tabular}{|c|c|c|c|c|}
\hline $\begin{array}{l}\text { Assessment } \\
\text { instrument }\end{array}$ & $\begin{array}{l}\text { Questionnaire } \\
\text { or interview }\end{array}$ & Construct & $\begin{array}{l}\text { Standardized/ } \\
\text { validated }\end{array}$ & $\begin{array}{l}\text { Age } \\
\text { of } \\
\text { the } \\
\text { child }\end{array}$ \\
\hline CRIES & questionnaire & $\begin{array}{l}\text { PTSD } \\
\text { symptoms }\end{array}$ & $\begin{array}{l}\text { yes, in USA } \\
\text { and in the } \\
\text { Netherlands }\end{array}$ & $\begin{array}{l}8-18 \\
\text { years }\end{array}$ \\
\hline CAPS-CA & interview & $\begin{array}{l}\text { PTSD diagnosis } \\
\text { and symptoms }\end{array}$ & $\begin{array}{l}\text { yes, in USA } \\
\text { and in the } \\
\text { Netherlands }\end{array}$ & $\begin{array}{l}\text { 8-18 } \\
\text { years }\end{array}$ \\
\hline InADES & questionnaire & $\begin{array}{l}\text { symptoms of } \\
\text { dissociation }\end{array}$ & $\begin{array}{l}\text { yes, in USA } \\
\text { and Turkey }\end{array}$ & $\begin{array}{l}12-20 \\
\text { years }\end{array}$ \\
\hline YSR & questionnaire & $\begin{array}{l}\text { internalizing } \\
\text { and } \\
\text { externalizing } \\
\text { symptoms }\end{array}$ & $\begin{array}{l}\text { yes, } \\
\text { internationally }\end{array}$ & $\begin{array}{l}11-18 \\
\text { years }\end{array}$ \\
\hline CPTCl & questionnaire & $\begin{array}{l}\text { negative } \\
\text { cognitions } \\
\text { about oneself } \\
\text { and the world }\end{array}$ & $\begin{array}{l}\text { yes, Dutch } \\
\text { study in } \\
\text { completion }\end{array}$ & $\begin{array}{l}8-18 \\
\text { years }\end{array}$ \\
\hline Kidscreen-10 & questionnaire & quality of life & $\begin{array}{l}\text { yes, } \\
\text { internationally }\end{array}$ & $\begin{array}{l}8-18 \\
\text { years }\end{array}$ \\
\hline
\end{tabular}

previous year's assessment as well as preparing the subsequent assessments.

\section{Statistical analysis}

Categorical data will be summarized as frequencies and percentages, continuous data will be summarized by means and standard deviations or median and interquartile scores, and if appropriate Linear mixed model analysis will be used to investigate the course of the outcomes of interest (e.g. PTSD dissociative symptoms) and to examine and test the effects of the various childand abuse characteristics on the outcomes. Longitudinal models for data assembled at T1 and further will have a random intercept to account for individual differences at baseline, fixed effects regression coefficients for each of the follow-up occasions after baseline while controlling for possible other confounding variables. The appropriate covariance structure for the longitudinal models and possible interaction effects will be assessed using loglikelihood statistics. Growth curves will be examined by plotting data and when appropriate we will include polynomials reflecting the observed curves. Cross-sectional

Table 3 Observation of parent-child play interaction

\begin{tabular}{|c|c|c|c|c|}
\hline & Type & Construct & $\begin{array}{l}\text { Standardized/ } \\
\text { validated }\end{array}$ & $\begin{array}{l}\text { Age } \\
\text { of } \\
\text { the } \\
\text { child }\end{array}$ \\
\hline $\begin{array}{l}\text { Strange } \\
\text { situation } \\
\text { procedure }\end{array}$ & $\begin{array}{l}\text { Observation of } \\
\text { child-parent } \\
\text { interaction }\end{array}$ & $\begin{array}{l}\text { Assessment of } \\
\text { quality of } \\
\text { attachment }\end{array}$ & $\begin{array}{l}\text { yes, } \\
\text { internationally }\end{array}$ & $\begin{array}{l}<8 \\
\text { years }\end{array}$ \\
\hline $\begin{array}{l}\text { DPICS/ } \\
\text { EAS }\end{array}$ & $\begin{array}{l}\text { observation of } \\
\text { parent-child } \\
\text { play } \\
\text { interaction }\end{array}$ & $\begin{array}{l}\text { assessment of } \\
\text { parenting and } \\
\text { quality of } \\
\text { interaction }\end{array}$ & $\begin{array}{l}\text { yes, } \\
\text { internationally }\end{array}$ & $\begin{array}{l}<8 \\
\text { years }\end{array}$ \\
\hline
\end{tabular}


comparisons at different time-points will also made using linear mixed model or ordinary multivariable regression analysis to examine the effects of child/parent and abuse characteristics on the outcomes.

\section{Confidentiality of study data}

The data for this study will be collected by researchers from the Department of Child and Adolescent Psychiatry at the AMC and the Department of Epidemiology and Health Promotion, at the Public Health Service in Amsterdam. The Clinical Research Unit of the AMC will be asked to build and manage the database for this project. The data will be stored in coded form by assigning a number to each file, questionnaire, and scoring sheet. This will prevent unauthorized persons from tracing which file belongs to which child or parents. Study results will also be published in anonymized form.

\section{Discussion}

The ASAC-study will be the first longitudinal study to systematically investigate signs and symptoms of sexual abuse in infants and very young children, and on boys in particular. These effects of the abuse will be measured at the short-, medium-, and long-term. The effects of the persistence of pornographic internet images, on the children and their parents, will also be investigated. Although CSA is common, it rarely occurs on the scale that it did in the Amsterdam sexual abuse case, committed by one chief perpetrator with one or two possible accomplices, and the severity of CSA is well documented by the police. Systematic research on the effects that CSA has on very young children is urgently needed to better understand the psychological and physical clinical presentations of such abuse and to identify the risk- and protective factors for psychopathology resulting from it. It is expected that CSA has effects on the child, parents, child-interaction and parental partner relation. This knowledge will enable early recognition of problems and prompt therapeutic intervention when CSA is suspected in very young children.

\section{Competing interests}

The authors declare that they have no competing interests.

\section{Authors' contributions}

$R L, S B, J D, E V, A T$ and $A V$ wrote the current manuscript. $R L, S B$ and $A V$ are the project leaders. $A T, S B$, and $T B$ are responsible for the first assessment in 2010. JD and EV are responsible for the assessment in 2013. All authors read and approved the final manuscript.

\section{Acknowledgments}

We would like to thank the following several mental health care agencies involved in the ASAC-study: Arkin Mental Health Care, 't Kabouterhuis Medical Day Care Centre for Children, GGZ inGeest Regional Mental Health Service Centre, Infant Mental Health Centre IMH, KJTC Haarlem, Slachtofferhulp, and De Bascule Academic Centre for Child and Adolescent Psychiatry. We would like to acknowledge the Research Advisory Committee: Marta Santos Pais, Anton Bentovim, Corianne de Borgie, Corinne Dettmeijer-Vermeulen, Danya Glaser, Eleanore Landsmeer-Beker, Robert Lindeboom, Anthony Mannarino, Miranda Olff, Michael Scheeringa, Steven Tjalsma, Frederike Scheper, Ethal Quayle, Guy
Widdershoven, and Jolien Zevalkink. We would also like to thank Els van Meijel, Maj Gigengack, Caroline Jonkman, and Marielle Abrahamse for collecting research data, and the children and parents for participating in our study. We would like to thank Pro Juventute and the Ministery of Security and Justice, and the Ministery of Health, Welfare and Sport.

\section{Author details}

${ }^{1}$ Department of Child and Adolescent Psychiatry, Academic Medical Centre, Amsterdam, The Netherlands. ${ }^{2}$ De Bascule, Academic Center for Child and Adolescent Psychiatry, Amsterdam, The Netherlands. ${ }^{3}$ Department of Social Pediatrics, Emma Children's Hospital, Academic Medical Centre, Amsterdam, The Netherlands. ${ }^{4}$ Department of Epidemiology \& Health Promotion, Public Health Services, Amsterdam, The Netherlands. ${ }^{5}$ Department of Child and Adolescent Psychiatry, GGZ-InGeest/NU University Medical Center, Amsterdam, Netherlands. ${ }^{6}$ Department of Biological Psychology, VU University, Amsterdam, The Netherlands. ${ }^{7}$ Department of Sociology and Antropology, University of Amsterdam, Amsterdam, The Netherlands.

Received: 29 September 2014 Accepted: 13 October 2014

Published online: 08 November 2014

\section{References}

1. Alink LRA, IJzendoorn MH v, Bakermans-Kranenburg MJ, Pannebakker F, Vogels T, Euser S: Kindermishandeling in Nederland anno 2010: De Tweede Nationale Prevalentiestudie Mishandeling van Kinderen en Jeugdigen (NPM-2010), [Child abuse and neglect in the Netherlands in 2010: The second national prevalence study on child abuse and neglect in children and adolescents]. Leiden: Casimir Publishers; 2011.

2. Finkelhor D, Ormrod R, Turner H, Hamby SL: The victimization of children and youth: a comprehensive, national survey. Child Maltreat 2005, 10:5-25.

3. Fontanella C, Harrington D, Zuravin SJ: Gender differences in the characteristics and outcomes of sexually abused preschoolers. J Child Sex Abus 2000, 9:21-40.

4. Lamers-Winkelman F, Slot NW, Bijl B, Vijlbrief AC: Scholieren over mishandeling. Resultaten van een landelijk onderzoek naar de omvang van kindermishandeling onder leerlingen van het voortgezet onderwijs, [Students about child abuse and neglect. Results of a national research study on the prevalence of child abuse and neglect in high school students]. 2007.

5. Stoltenborgh M, van IJzendoorn MH, Euser EM, Bakermans-Kranenburg MJ: A global perspective on child sexual abuse: meta-analysis of prevalence around the world. Child Maltreat 2011, 26:79-101.

6. Turner HA, Finkelhor D, Ormrod R, Hamby SL: Infant victimization in a nationally representative sample. Pediatrics 2010, 126:44-52.

7. Van IJzendoorn MH, Prinzie P, Euser EM, Groeneveld MG, Brilleslijper-Kater SN, der Linden AMT VN-V, Bakermans-Kranenburg MJ, Juffer F, Mesman J, Klein Vlederman M, San Martin Beuk M: Kindermishandeling in Nederland anno 2005: de Nationale Prevalentiestudie Mishandeling van kinderen en jeugdigen (NPM-2005), [Child abuse and neglect in the Netherlands in 2005: The national prevalence study in children and adolescents]. Leiden, the Netherlands: WODC, Universiteit Leiden; 2007.

8. Bremner JD: Long-term of childhood abuse on brain and neurobiology. Child Adolesc Psychiatr Clin North American 2003, 12:271-292.

9. Browne A, Finkelhor D: Impact of child sexual abuse: a review of the research. Psychol Bull 1986, 99:66-77.

10. Coates S, Gaensbauer TJ: Event trauma in early childhood: symptoms, assessment, intervention. Child Adolesc Psychiatr Clin North American 2009, 18:611-626.

11. Kelley SJ, Brant R, Waterman J: Sexual abuse of children in day care centers. Child Abuse Negl 1993, 17:71-89.

12. Maniglio R: The impact of child sexual abuse on health: a systematic review of reviews. Clin Psychol Rev 2009, 29:647-657.

13. Mian M, Wehrspann W, Klajner-Diamond H, LeBaron D, Winder C: Review of 125 children 6 years of age and under who were sexually abused. Child Abuse Negl 1986, 10:223-229.

14. Paolucci EO, Genius ML, Violato CA: Meta-analysis of the published research on the effects of child sexual abuse. J Psychol 2001, 135:17-36.

15. Perry BD: Examining child maltreatment through a neurodevelopmental lens: clinical applications of the neurosequential model of therapeutics. J Loss Trauma 2009, 14:240-255.

16. Putnam FW: Ten-years research update review: child sexual abuse. J Am Acad Child Adolesc Psychiatry 2003, 42:269-278. 
17. Beitchman JH, Zucker KJ, Hood JE, DaCosta GA, Akman D: A review of the short-term effects of child sexual abuse. Child Abuse Neg/ 1991, 15:537-556.

18. Chu AT, Lieberman AF: Clinical implications of traumatic stress from birth to age five. Annu Rev Clin Psychol 2010, 6:469-494.

19. Ehrensaft D: Preschool child sexual abuse: the aftermath of the Presidio case. Am J Orthopsychiatry 1992, 62:234-244.

20. Faller KC: The spectrum of sexual abuse in daycare: an exploratory study. $J$ Violence 1988, 3:283-298.

21. Finkelhor D, Meyer Williams L, Burns N: Nursery crimes: Sexual abuse in Day Care. Newbury Park: Sage Publications; 1988.

22. Gale J, Thompson RJ, Moran T, Sack WH: Sexual abuse in young children: its clinical presentation and characteristics patterns. Child Abuse Negl 1988, 12:163-170.

23. Hall DK, Mathews F, Pearce J: Factors associated with sexual behavior problems in young sexually abused children. Child Abuse Negl 1998, 22:1045-1063.

24. Ligezinska M, Firestone P, Manion IG, Mclntyre J, Ensom R, Wells G: Children's emotional and behavioral reactions following the disclosure of extrafamilial sexual abuse: initial effects. Child Abuse Negl 1996, 20:111-125.

25. Lindauer RJL, Boer F: Trauma bij kinderen, [Trauma in children]. Houten: LannooCampus; 2012.

26. McClellan J, McCrery C, Ronnie R, Adams J, Eisner A, Storck M: Age of onset of sexual abuse: relationship to sexually inappropriate behaviors. J Am Acad Child Adolesc Psychiatry 1996, 34:1375-1383.

27. Negriff S, Noll JG, Shenk CE, Putman FW, Trickett PK: Associations between nonverbal behaviors and subsequent sexual attitudes and behaviors of sexually abused and comparison girls. Child Maltreat 2010, 15:180-189.

28. Noll JG, Trickett PK, Putnam FW: A prospective investigation of the impact of childhood sexual abuse on the developmental of sexuality. J Consult Clin Psychol 2003, 71:575-586.

29. Ogawa JR, Soufre LA, Weinfield NS, Carlson EA, Egeland B: Development and the fragmented self: longitudinal study of dissociative symptomatology in a nonclinical sample. Dev Psychopathol 1997, 9:855-879.

30. Salmon K, Bryant RA: Posttraumatic stress disorder in children. The influence of developmental factors. Clin Psychol Rev 2002, 22:163-188.

31. Scarborough AA, Lloyd EC, Barth RP: Maltreatment infants and toddlers: predictors of developmental delay. J Dev Behav Pediatr 2009, 30:489-498.

32. Kelley SJ: Stress responses of children to sexual abuse and ritualistic abuse in day care centers. J Interpers Violence 1989, 4:502-513.

33. Dyb G, Holen A, Steinberg AM, Rodriguez N, Pynoos RS: Alleged sexual abuse at a day care center: impact on parents. Child Abuse Negl 2003, 27:939-950.

34. Burgess AW, Hartman CR, Kelley SJ, Grant CA, Gray EB: Parental response to child sexual abuse trials involving day care settings. J Trauma Stress 1990, 3:395-405.

35. Burgess AW, Hartman CR: Children's adjustment 15 years after daycare abuse. J Forensic Nurs 2005, 83:73-77.

36. Cutajar MC, Mullen PE, Ogloff JRP, Thomas SD, Wells DL, Spataro J: Psychopathology in a large cohort of sexually abused children followed up to 43 years. Child Abuse Negl 2010, 34:813-822

37. Dube SR, Anda RF, Whitfield CL, Dube SR, Anda RF, Whitfield CL, Brown DW, Felitti VJ, Dong M, Giles WH: Long-term consequences of childhood sexual abuse by gender of victim. Am J Prev Med 2005, 28:430-438.

38. Irish L, Kobayashi I, Delahanty DL: Long-term physical health consequences of childhood sexual abuse: a meta-analytic review. J Pediatr Psychol 2010, 35:450-461.

39. Keiley MK, Howe TR, Dodge KA, Bates JE, Petti GS: The timing of child physical maltreatment: a cross-domain growth analysis of impact on adolescent externalizing and internalizing problems. Dev Psychopathol 2001, 13:891-912.

40. Felitti $\bigvee$ J: The relationship of adverse childhood experiences to adult health: turning gold into lead. Psychosom Med Psychother 2002, 48:359-369.

41. Rohde P, Ichikawa L, Simon GE, Ludman EJ, Linde JA, Jeffery RW, Operskalski $\mathrm{BH}$ : Associations of child sexual and physical abuse with obesity and depression in middle-aged women. Child Abuse Negl 2008, 32:878-887.

42. Collings SJ: The long-term effects of contact and noncontact forms of child sexual abuse in a sample of University Men. Child Abuse Negl 1995, 19:1-6.

43. Kendall-Tackett KA, Meyer Williams L, Finkelhor D: Impact of sexual abuse in Children: a review and synthesis of recent empirical studies. Psychol Bull 1993, 113:164-180.
44. Tremblay C, Hebert M, Piche C: Coping strategies and social support as mediators of consequences in child sexual abuse victims. Child Abuse Negl 1999, 23:929-945.

45. Cornelis MC, Nugent NR, Amstadter AB, Koenen KC: Genetics of posttraumatic stress disorder: review and recommendations for genome-wide association studies. Curr Psychiatry Rep 2010, 12:313-326.

46. Sullivan PF, Daly MJ, O'Donovan M: Genetic architectures of psychiatric disorders: the emerging picture and its implications. Nat Rev Genet 2012 13:537-551.

47. Logue MW, Baldwin C, Guffanti G, Melista E, Wolf EJ, Reardon AF, Uddin M, Wildman D, Galea S, Koenen KC, Miller MW: A genome-wide association study of post-traumatic stress disorder identifies the retinoid-related orphan receptor alpha (RORA) gene as a significant risk locus. Mol Psychiatry 2013, 18:937-942. Aug 7.doi:10.1038/mp.2012.113. [Epub ahead of print] PubMed PMID: 22869035.

48. Pitman RK, Rasmusson AM, Koenen KC, Shin LM, Orr SP, Gilbertson MW, Milad MR, Liberzon I: Biological studies of post-traumatic stress disorder. Nat Rev Neurosci 2012, 13(11):769-787. doi: 10.1038/nrn3339.

49. van Bakel HJA, Riksen-Walraven JM: Parenting and development of one-year-olds: links with parental, contextual, and child characteristics. Child Dev 2002, 73:256-273.

50. Manion IG, McIntyre J, Firestone P, Ligezinska M, Ensom R, Well G: Secondary traumatization in parents following the disclosure of extrafamilial child sexual abuse: initial effects. Child Abuse Negl 1996 19:399-408.

51. Davies MG: Parental distress and ability to cope following disclosure of extra-familial sexual abuse. Child Abuse Negl 1995, 19:399-408.

52. Esquilin SC: Family response to the identification of extrafamilial child sexual abuse. Psychother Priv Pract 1987, 5:105-113.

53. Kelley SJ: Parental stress response to sexual abuse and ritualistic abuse of children in day-care centers. Nurs Res 1990, 39:25-29.

54. Reyman MB: Family responses to extrafamilial child sexual abuse: an overview and an experiential perspective. Issues Compr Pediatr Nurs 1990 13:203-220.

55. Timmons-Mitchell J, Chandler-Holtz D, Semple WE: Post-traumatic stress symptoms in mothers following children's reports of sexual abuse: an exploratory study. Am J Orthopsychiatry 1996, 66:463-467.

56. Wagner WG: Depression in mothers of sexually abused vs. mothers of nonabused children. Child Abuse Negl 1991, 15:99-104.

57. Bhandari S, Winter D, Messer D, Metcalfe C: Family characteristics and long-term effects of childhood sexual abuse. Br J Clin Psychol 2011 50:435-451.

58. Leventhal JM, Murphy $J$, Asnes AG: Evaluations of child sexual abuse: recognition of overt and latent family concerns. Child Abuse Negl 2010 34:289-295.

59. Wind TW, Silvern L: Parenting and family stress as mediators of the longterm effects of child-abuse. Child Abuse Negl 1994, 18:439-453.

60. Cicchetti D, Rogosch FA, Gunnar MR, Toth SL: The differential impacts of early physical and sexual abuse and internalizing problems on daytime cortisol rhythm in school-aged children. Child Dev 2010, 81:252-269.

61. Dutra L, Bureau J-F, Holmes B, Lyubchik A, Lyons-Ruth K: Quality of early care and childhood trauma: a prospective study of developmental pathways to dissociation. J Nerv Ment Dis 2009, 197:383-390.

62. Fisher PA, Stoolmiller M, Gunnar MR, Burraston BO: Effects of therapeutic intervention for preschoolers on diurnal cortisol activity. Psychoendocrinol 2011, 23:453-476.

63. Hulme PA: Childhood sexual abuse, HPA axis regulation, and mental health: an integrative review. West J Nurs Res 2010, 33:1069-1097.

64. Labonté B, Suderman M, Maussion G, Navaro L, Yerko V, Mahar I, Bureau A, Mechawar N, Szyf M, Meaney MJ, Turecki G: Genome-wide epigenetic regulation by early-life trauma. Arch Gen Psychiatry 2012, 69:722-731.

65. Perry BD: Childhood experience and the expression of genetic potential: what childhood neglect tells us about nature and nurture. Brain Mind 2002, 3:79-100.

66. Rosler A: Long-term effects of childhood sexual abuse on the hypothalamicpituitary-adrenal axis. J Clin Endocrinol Metabol 1994, 78:247-248.

67. Nationaal rapporteur mensenhandel: Kinderpornografie-Eerste rapportage van de Nationaal Rapporteur, [Child pornography - First report from the Dutch Rapporteur]. Den Haag: BNRM; 2011.

68. Ost S: Child pornography and sexual grooming. Legal and societal responses. Cambridge (UK): Cambridge University Press; 2009. 
69. Taylor M, Quayle E: Child pornography. An internet crime. East Sussex (UK): Brunner-Routledge; 2003.

70. Adams JA, Harper K, Knudson S, Revilla J: Examination findings in legally confirmed child sexual abuse: it's normal to be normal. Pediatrics 1994, 94:310-317.

71. Berenson AB, Chacko MR, Wiemann CM, Mishaw CO, Friedrich WN, Grady JJ: A case-control study of anatomic changes resulting from sexual abuse. Am J Obstet Gynecol 2000, 182(4):820-831.

72. Emans SJ, Woods ER, Flagg NT, Freeman A: Genital findings in sexually abused, symptomatic and asymptomatic, girls. Pediatrics 1987, 79(5):778-785.

73. Lindblad F, Kaldal A: Sexual abuse at a Swedish daycare centre: allegations, confessions and evaluations. Acta Paediatr 2000, 89:1001-1009.

74. Gaensbauer TJ: Representations of trauma in infancy: clinical and theoretical implications for the understanding of early memory. Infant Ment Health J 2002, 23:259-277.

75. Hewitt S: Preverbal children: sexual abuse: what to report in later years. Child Abuse Negl 1994, 18:821-826.

76. Schumacher RB, Carlson RS: Variables and risk factors associated with child abuse in daycare settings. Child Abuse Negl 1999, 23:891-898.

77. Terr L: What happens to early memories of trauma? a study of twenty children under age five at the time of documented traumatic events. J Am Acad Child Adolesc Psychiatry 1988, 27:96-104.

78. Berenson AB, Chacko MR, Wiemann CM, Mishaw CO, Friedrich WN, Grady JJ: Use of hymenal measurements in the diagnosis of previous penetration. Pediatrics 2002, 109:228-235.

79. Finkel MA: Medical Aspects of Prepubertal Sexual Abuse. Child abuse: Medical diagnosis and management. 3rd edition. Elk Grove Village: American Academy of Pediatrics; 2009:269-320.

80. Heger A, Ticson L, Velasquez O, Bernier R: Children referred for possible sexual abuse: medical findings in 2384 children. Child Abuse Negl 2002, 26:645-659.

81. Schaie KW, Hertzog C: Longitudinal methods. In Handbook of Developmental Psychology. Edited by Wolman BB. New York: Prentice Hall; 1982.

82. Trickett PK, Noll JG, Putnam FW: The impact of sexual abuse on female development: lessons from a multigenerational, longitudinal research study. Dev Psychopathol 2011, 23:453-476.

83. Adams JA: Medical evaluation of suspected child sexual abuse: 2011 update. J Child Sex Abuse 2011, 20:588-605.

84. Adams JA: Evolution of a classification scale: medical evaluation of suspected child sexual abuse. Child Maltreat 2001, 6:31.

85. Adams JA: Guidelines for medical care of children evaluated for suspected sexual abuse: an update for 2008. Curr Opin Obstet Gynecol 2008, 20:435-441.

86. Adams JA, Kaplan RA, Starling SP, Adams JA, Kaplan RA, Starling SP, Mehta $\mathrm{NH}$, Finkel MA, Botash AS, Kellogg ND, Shapiro RA: Guidelines for medical care of children who may have been sexually abused. J Pediatr Adolesc Gynaecol 2007, 20:163-172.

87. Brilleslijper-Kater SN: Beyond words: between-group differences in the ways sexually abused and nonabused preschool children reveal sexual knowledge. Dissertation. 2005:1-173.

88. Children and War Foundation: Children's Impact of Event Scale (CRIES-13). 1998. See http://www.childrenandwar.org.

89. Perrin S, Meiser-Stedman R, Smith P: The Children's Revised Impact of Event Scale (CRIES): validity as a screening instrument for PTSD. Behav Cogn Psychother 2005, 33:487-498.

90. Smith P, Perrin S, Dyregov A, Yule W: Principal component analysis of the impact of event scale in children in war. Pers Indiv Differ 2003, 34:315-322.

91. Verlinden E, van Meijel EPM, Opmeer BC, Beer R, de Roos C, Bicanic IAE, Lindauer RJL: Characteristics of the Children's Revised Impact of Event Scale (CRIES) in a clinically referred Dutch sample. J Trauma Stress 2014, 27:338-344. doi:10.1002/jts.21910

92. Scheeringa MS, Haslett N: The reliability and criterion validity of the diagnostic infant and preschool assessment: a new diagnostic instrument for young children. Child Psychiatry Hum Dev 2010, 41:299-312.

93. Scheeringa MS, Zeanah $\mathrm{CH}$, Myers $\mathrm{L}$, Putnam FW: Predictive validity in a prospective follow-up of PTSD in Preschool Children. J Am Acad Child Adolesc Psychiatry 2005, 44:899-906.

94. Silverman WK, Albano AM: Anxiety Disorders Interview Schedule for DSM-IV. San Antonio: The Psychological Corporation; 1996.

95. Siebelink BM, Treffers PDA: Nederlandse bewerking van Anxiety Disorders Interview Schedule for DSM-IV: Child Version (Child Interview Schedule; Parent Interview Schedule; Manual). Lisse: Swets \& Zeitlinger; 2001.
96. Lyneham HJ, Abbott MJ, Rapee RM: Interrater reliability of the anxiety disorders interview schedule for DSM-IV: Child and parent version. J Am Acad Child Adolesc Psychiatry 2007, 46:731-736. doi:10.1097/chi.0b013e3180465a09.

97. Silverman WK, Saavedra LM, Pina AA: Test-retest reliability of anxiety symptoms and diagnoses with anxiety disorders interview schedule for DSM-IV: child and parent versions. J Am Acad Child Adolesc Psychiatry 2001, 40:937-944. doi:10.1097/00004583-200108000-00016.

98. Putnam FW, Helmers K, Trickett PK: Development, reliability, and validity of a child dissociation scale. Child Abuse Negl 1993, 17:731-741.

99. Hartveld G, Janssen M: Nederlandse vertaling van de Child Dissociative Checklist (CDC). Amsterdam: Vrije Universiteit; 1992.

100. Polderman N, Kellaert-Knoll MG, Storsbergen H, Bongaerts WB, Corts M, De Pagter JN: Manual of the attachment difficulties screening inventory 2-5 years (AISI 2-5 years). Haarlem, The Netherlands: Basic Trust; 2008.

101. Polderman N: GIH (Globale Indicatielijst Hechting) 2-18 jaar. [Global Indicationlist Attachment age 2-18]. the Netherlands: Polder-man/FlexusJeugdplein Rotterdam; 2009.

102. Friedrich WN: Child Sexual Behavior Inventory (CSBI) Professional Manual. Psychological Assessment Resources, Inc: Odessa, Florida; 1997.

103. Schoentjes $E$, Lamers-Winkelman F: Experimentele Nederlandse vertaling van de Child Sexual Behavior Inventory (CSBI), [Dutch translation of the CSBI]. Amsterdam: Vrije Universiteit; 1998.

104. Friedrich WN, Grambsch P, Damon L, Hewitt SK, Koverola C, Lang RA, Wolfe $\checkmark$, Broughton D: Child sexual behavior inventory: normative and clinical comparisons. Psychol Assess 1992, 4:303-311.

105. Achenbach TM, Rescorla LA: Manual for the ASEBA Adult Forms \& Profiles. Burlington, Vermont: University of Vermont, Research Center for Children, Youth, \& Families; 2003.

106. Ravens-Sieberer U, Erhart M, Rajmil L, Herdman M, Auquier P, Bruil J, Power M, Duer W, Abel T, Czemy L, Mazur J, Czimbalmos A, Tountas Y, Hagquist C, Kilroe J, the European KIDSCREEN Group: Reliability, construct and criterion validity of the KIDSCREEN-10 score: a short measure for children and adolescents' well-being and health-related quality of life. Qual Life Res 2010, 19:1487-1500.

107. Weiss DS, Marmar CR: The Impact of Event Scale - Revised. In Assessing psychological trauma and PTSD. Edited by Wilson J, Keane TM. New York Guilford; 1996:399-411.

108. Mannarino AP, Cohen JA: A follow-up study of factors that mediate the development of psychological symptomatology in sexually abused girls. Child Maltreat 1996, 1:246-260.

109. Brennan KA, Clark CL, Shaver PR: Self-Report Measurement of Adult Attachment: An Integrative Overview. In Attachment Theory and Close Relationships. Edited by Simpson JA, Rholes WS. New York: The Guilford Press; 1998.

110. Conradi HJ, Gerlsma C, van Duijn M, de Jonge P: Internal and external validity of the experiences in close relationships questionnaire in an American and two Dutch samples. Eur J Psychiat 2006, 20:258-269.

111. Wei M, Russell DW, Mallinckrodt B, Vogel DL: The Experiences in Close Relationship Scale (ECR)-short form: reliability, validity, and factor structure. J Pers Assess 2007, 88:187-204.

112. Verlinden E, van Laar YL, van Meijel EPM, Opmeer BC, Beer R, de Roos C, Lindauer RJL: A parental tool to screen for posttraumatic stress in children: First psychometric results. J Trauma Stress 2014, doi:10.1002/jts.21929.

113. Nader K, Kriegler J, Blake DD, Pynoos R, Newman E, Weather F: Clinician administered PTSD Scale, Child and Adolescent Version. White River Junction, VT: National Center for PTSD; 1996.

114. Diehle J, de Roos C, Boer F, Lindauer RJL: A cross-cultural validation of the clinician administered PTSD Scale for children and adolescents in a Dutch population. Eur J Psychotraumato/ 2013, 4:19896. doi:http://dx.doi. org/10.3402/ejpt.v4i0.19896.

115. Meiser-Stedman R, Smith P, Bryant R, Salmon K, Yule W, Dalgleish T, Nixon RDV: Development and validation of the Child Post-Traumatic Cognitions Inventory (CPTCI). J Child Psychol Psychiatr 2009, 50:432-440.

116. Armstrong JG, Putnam FW, Carlson EB, Armstrong JG, Putnam FW, Carlson EB, Libero DZ, Smith SR: Development and validation of a measure of adolescent dissociation: the adolescent dissociative experiences scale. J Nerv Ment Dis 1997, 185:491-497.

117. Ainsworth MDS, Blehar M, Waters E, Wall S: Patterns of attachment. A psychological study of the strange situation. Hillsdale: NJ Erlbaum; 1978.

118. Cassidy J, Marvin RS: Attachment organization in preschool children: Procedures and coding manual, MacArthur Network on the transition from infancy to early childhood. Seattle, WA: John D. and Catherine T; 1992. 
119. Eyberg SM, Nelson MM, Duke M, Boggs SR: Manual for the Dyadic Parent-Child Interaction Coding System. 3rd edition. Florida, USA: University of Florida: Child Study Laboratory; 2005.

120. Biringen Z: Emotional availability: conceptualization and research findings. In American Journal Interaction Coding System. 3rd edition. Florida, USA: University of Florida: Child Study Laboratory; 2000.

doi:10.1186/s12888-014-0295-7

Cite this article as: Lindauer et al:: The Amsterdam Sexual Abuse Case (ASAC)-study in day care centers: longitudinal effects of sexual abuse on infants and very young children and their parents, and the consequences of the persistence of abusive images on the internet. BMC Psychiatry 2014 14:295.

\section{Submit your next manuscript to BioMed Central and take full advantage of:}

- Convenient online submission

- Thorough peer review

- No space constraints or color figure charges

- Immediate publication on acceptance

- Inclusion in PubMed, CAS, Scopus and Google Scholar

- Research which is freely available for redistribution 